\title{
Revalideren is goed schakelen!
}

Citation for published version (APA):

Smeets, R. J. E. M. (2011). Revalideren is goed schakelen! Océ Business Services. https://doi.org/10.26481/spe.20110401rs

Document status and date:

Published: 01/04/2011

DOI:

10.26481/spe.20110401rs

Document Version:

Publisher's PDF, also known as Version of record

\section{Please check the document version of this publication:}

- A submitted manuscript is the version of the article upon submission and before peer-review. There can be important differences between the submitted version and the official published version of record.

People interested in the research are advised to contact the author for the final version of the publication, or visit the DOI to the publisher's website.

- The final author version and the galley proof are versions of the publication after peer review.

- The final published version features the final layout of the paper including the volume, issue and page numbers.

Link to publication

\footnotetext{
General rights rights.

- You may freely distribute the URL identifying the publication in the public portal. please follow below link for the End User Agreement:

www.umlib.nl/taverne-license

Take down policy

If you believe that this document breaches copyright please contact us at:

repository@maastrichtuniversity.nl

providing details and we will investigate your claim.
}

Copyright and moral rights for the publications made accessible in the public portal are retained by the authors and/or other copyright owners and it is a condition of accessing publications that users recognise and abide by the legal requirements associated with these

- Users may download and print one copy of any publication from the public portal for the purpose of private study or research.

- You may not further distribute the material or use it for any profit-making activity or commercial gain

If the publication is distributed under the terms of Article $25 \mathrm{fa}$ of the Dutch Copyright Act, indicated by the "Taverne" license above, 


\section{Maastricht University}

Prof. dr. Rob J.E.M. Smeets

Faculty of Health, Medicine and Life Sciences

Revalideren is goed schakelen! 
Revalideren is goed schakelen! 


\section{Colofon}

Ontwerp en print: Océ Business Services, Maastricht

ISBN: 978-905-681-363-5

NUR: 870

Alle rechten voorbehouden. Niets uit deze uitgave mag worden verveelvoudigd, opgeslagen in een geautomatiseerd gegevensbestand of openbaar gemaakt worden, zonder voorafgaande schriftelijke toestemming van de auteur of uitgever. 


\section{Revalideren is goed schakelen!}

Maastricht, april 2011

Prof. dr. Rob J.E.M. Smeets 
Revalideren is goed schakelen! 
Mijnheer de rector magnificus, geachte College van Bestuur, mijnheer de decaan, geachte Raden van Bestuur, zeer gewaardeerde collega's, familie, vrienden en andere toehoorders.

Ik heet iedereen van harte welkom op deze voor mij mooie dag en ik ben verheugd dat $u$ met zo velen naar deze openbare lezing bent gekomen. Nu ik met het uitspreken van deze rede mijn functie als hoogleraar officieel aanvaard, realiseer ik mij maar al te goed dat dit een zeer bijzondere mijlpaal is in de ontwikkeling van ons mooie vak; het laatste UMC in Nederland is nu ook voorzien van een hoogleraar revalidatiegeneeskunde!

Ik wil u meenemen op mijn voorgenomen reis die ik zal illustreren aan de hand van mijn favoriete vervoermiddel, de fiets. Bij de fiets is de sterkte van de schakels die samen de ketting vormen en het goed schakelen van het allergrootste belang om de gewenste eindbestemming te bereiken.

Wie in de middeleeuwen 'gehandicapt' raakte, als hij het oorzakelijk lijden al overleefde, moest zich wenden tot de kerk of stad voor enige hulp. Pas ten gevolge van de eerste wereldoorlog kwam de revalidatie door de vele oorlogsslachtoffers in Europa goed op gang. Maar in Nederland was het wachten tot na de tweede wereldoorlog. Door de wederopbouw bestond er een grote behoefte aan arbeidskrachten, ook aan hen die lichamelijke beperkingen hadden. De ontwikkeling werd verder bespoedigd door de ontdekking van antibiotica die het kuren voor TBC overbodig maakten waardoor voor de sanatoria een nieuwe bestemming moest worden gezocht. Vanaf de oprichting van de beroepsvereniging in 1955 heeft de revalidatiegeneeskunde een boeiende ontwikkeling doorgemaakt, al hoewel het tot 1977 duurde voordat het als een officieel medisch specialisme werd erkend. Intussen behoort de Nederlandse revalidatiegeneeskunde, samen met de Angelsaksische en Scandinavische landen tot de mondiale top.

Voor Limburg was de ontwikkeling iets trager met in 1962 de start van revalidatiegeneeskunde in het ziekenhuis St. Annadal te Maastricht en in 1969 de opening van het klinisch revalidatiecentrum te Hoensbroek en de start van de kinderrevalidatie te Houthem-Valkenburg.

Geleidelijk aan kwam in Nederland meer oog voor community based revalidatie en de daarbij horende ziekenhuisrevalidatie groeide dan ook gestaag. Anno 2011 beschikt ieder ziekenhuis over een afdeling revalidatiegeneeskunde en zorgen 23 revalidatiecentra voor een volledige 
regionale dekking van de klinische revalidatie. Tevens is medisch specialistische revalidatie onderdeel van het basispakket zorgverzekering. In 2009 behandelden ruim 400 revalidatieartsen 75.000 patiënten, van wie ruim 8.000 klinisch en adviseerden ze minstens evenzoveel patiënten in de vorm van informatieverstrekking, behandeladvies, voorschrijven van hulpmiddelen zoals orthese of schoeisel et cetera. Nederland geeft in totaal 58 miljard aan de gezondheidszorg uit, waarvan 40\% voor de curatieve zorg. Het aandeel van de revalidatiesector bedraagt slechts $2 \%$.' Dus we zijn een relatief kleine speler in dit veld maar daarom niet minder belangrijk. We zijn een jong volwassen specialisme dat echter nog veel meer te bieden heeft, zeker waar het de verschillende plekken c.q. schakels in de ketenzorg betreft, maar daarover zo meteen meer.

Het vak is wetenschappelijk gezien een jonge adolescent met een enorm groeipotentieel. Begin jaren 90 werd gestart met het opleiden van revalidatieartsen tot onderzoeker onder de bezielende leiding van Dr. Jos op 't Root, medewerker van de vakgroep Huisartsgeneeskunde van de Universiteit Maastricht. Maar de echte stap voorwaarts werd eind jaren 90 gemaakt door het instellen van het door ZonMW gecoördineerd onderzoeksprogramma Revalidatie. Hierdoor werd het revalidatieonderzoek in Nederland duidelijk gestimuleerd en beter ingebed in de medische faculteiten. ${ }^{2}$ Dit programma heeft er mede toe bijgedragen dat ik hier vandaag voor u sta. In 2006 volgde een wederom succesvol tweede programma en momenteel wordt gewerkt aan het instellen van een derde, laatste ronde waarna ons vakgebied voldoende in staat moet worden geacht op eigen kracht c.q. twee wielen verder te kunnen.

Intussen kan het Nederlandse revalidatieonderzoek zich meten met de wetenschappelijke prestaties van vooraanstaande internationale onderzoeksgroepen, getuige de kwaliteit van ons meest recente internationaal VRA-jaarcongres. Het door meerdere van onze leden nog ervaren ongemak van Engels als voertaal, lijkt een laatste stuiptrekking bij de definitieve overgang naar volwassenheid. Concluderend, er is een stevig - maar door de aankomende bezuinigingen overigens nog erg kwetsbaar - fundament voor de academisering van het vak gelegd. Hoe ik samen met mijn vakgroep dit fundament verder wil versterken en daarvandaan naar een hogere versnelling wil schakelen, belicht ik in het derde deel van mijn verhaal. 
Nu ga ik over tot een korte kenschets van het vak revalidatiegeneeskunde gevolgd door een bespreking van belangrijke ontwikkelingen en daaruit voortvloeiende consequenties voor onze rol of beter gezegd schakelpositie in de belangrijkste keten, namelijk de zorgketen.

\section{Definitie revalidatiegeneeskunde}

Volgens de European Union of Medical Specialists-sectie Physical Rehabilitation Medicine is revalidatiegeneeskunde een onafhankelijk specialisme dat zich richt op de zorg voor mensen met (dreigende) problemen van het bewegingsapparaat die (kunnen) leiden tot blijvende verstoring van het functioneren. Het houdt zich bezig met het bevorderen van fysiek en cognitief functioneren, activiteiten, participatie en het veranderen van persoonlijke en omgevingsfactoren. Het vak kent de functies diagnostiek, advisering, behandeling en nazorg.3.4

Kenmerkend voor de revalidatiegeneeskunde is dat niet de aandoening/ ziekte centraal staat zoals nog vaak gebeurt in het medisch gevolgen model maar de mens. Vanuit dit holistisch perspectief, ook wel biopsychosociaal denken genoemd, tracht de revalidatiearts, eventueel samen met zijn interdisciplinair team helder te krijgen wat de gevolgen van deze aandoening/ziekte en de beïnvloedende factoren zijn. Hiertoe wordt gebruik gemaakt van de door de World Health Organisation ontwikkelde International Classification of Functioning, Disability and Health (ICF-model). ${ }^{5}$

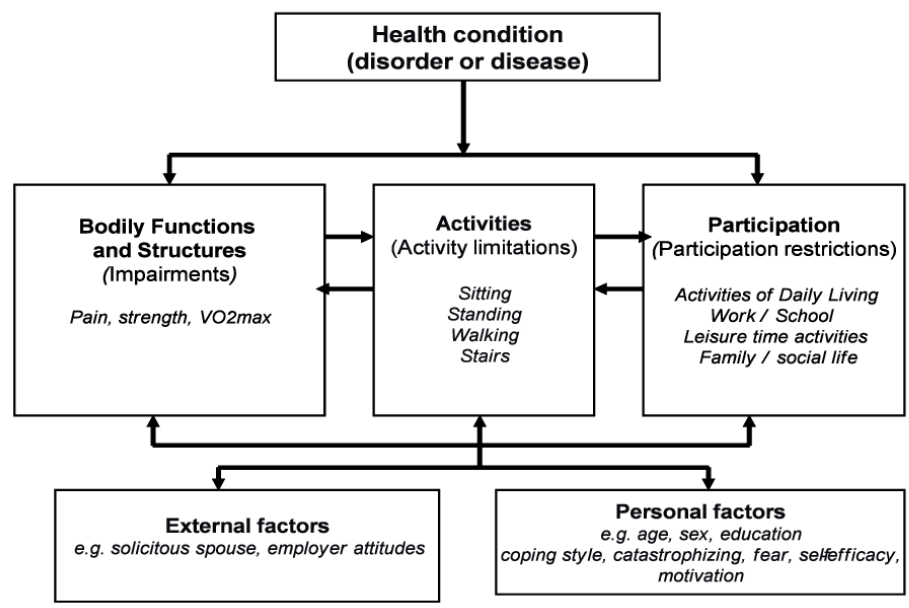


Op basis van dit model wordt eerst de door de ziekte/ongeval ontstane somatische problematiek in kaart gebracht. Hierbij worden fysieke functies zoals pijn, verlies aan kracht en sensibiliteit maar ook cognitieve functies zoals geheugen en concentratie, onderscheiden. Vervolgens wordt beoordeeld of deze gestoorde functies beïnvloedbaar zijn. Daarnaast worden de gevolgen op het gebied van activiteiten (zoals lopen, staan, traplopen, ADL) en participatie (de maatschappelijke rollen die een persoon uitoefent of wenst uit te oefenen) vastgesteld. Aangezien juist persoonlijke factoren (motivatie, karakter, angst en depressie) als ook de omgeving (partner, woning en werkgever) een zeer belangrijke bijdrage leveren aan de wijze waarop de persoon met de ziekte/ aandoening functioneert, worden deze eveneens geïnventariseerd. De patiënt wordt als belangrijkste schakel, uitdrukkelijk gevraagd zijn hulpvraag te formuleren en bij het vaststellen van de behandeldoelstellingen betrokken.

Uiteraard worden functies die nog beïnvloedbaar zijn, aangepakt (trainen kracht en conditie, verminderen contracturen etc.). Echter, meestal zal de behandeling ook en soms in hoofdzaak gericht zijn op het beïnvloeden van omgeving- en persoonlijke factoren en het optimaliseren van de activiteiten en participatieniveau. Maar het is van eminent belang dat de eigen verantwoordelijkheid van de patiënt wordt bevorderd om zo meer blijvende autonomie en kwaliteit van leven te bewerkstelligen. De patiënt wordt daarom ook gestimuleerd om zelf een plan te maken voor het behoud van het bereikte resultaat.

Ik wil benadrukken dat de revalidatiegeneeskunde zich niet alleen op de gevolgen van een ziekte/ongeval richt, maar ook op de PREVENTIE van secundaire gevolgen van de door ziekte/ongeval veroorzaakte problemen en dus ook onze inzet vroeg in de zorgketen van groot belang is.

Ik wil nog een versnelling hoger schakelen en poneren dat we ook een bijdrage moeten leveren aan primaire preventie. Zo hebben we uit wetenschappelijk onderzoek en de behandeling bij mensen met chronische pijnklachten in het bewegingsapparaat inzicht gekregen in risicofactoren voor het ontstaan en in stand houden van de gevolgen van deze klachten. Deze inzichten zijn uitstekend bruikbaar voor een in mijn ogen absoluut noodzakelijke nationale voorlichtingscampagne rondom lage rugklachten. Uit eerder onderzoek o.a. in Australië en Canada blijkt dat een dergelijke campagne alleen effectief is als hierbij 
alle beschikbare media worden ingezet zoals radio en tv en nu uiteraard ook alle nieuwe vormen van sociale media. ${ }^{6,8}$

Verder kunnen we onze opgedane kennis t.a.v. het motiveren van patiënten tot gedragsverandering ter beschikking stellen om mensen meer te laten bewegen en gezonder oud te laten worden. Om meteen de daad bij het woord te voegen. Het $M U M C^{+}$benadrukt met haar motto 'Heel de Mens' het belang van gezond gedrag. Terugdenkend aan mijn studententijd zie ik nog de hal van het St. Annadal ziekenhuis voor me waar patiënten, bezoekers en dokters gebroederlijk zoals het echte Bourgondiërs betaamt in de bar genoten van drank en rookwaren. Komt u nu bijna 30 jaar later op het poliplein, na overigens wel een behoorlijke wandeling vanaf het parkeerdek zeker voor onze patiënten, dan kunt $u$ het verlies aan energie ruimschoots compenseren met een vette hap. Ik hoop dat $u$ en ik op zeer korte termijn alleen nog maar gezonde fruit- en groentedrankjes mogen aantreffen binnen het $\mathrm{MUMC}^{+}$!

\section{Ontwikkelingen binnen het vak en consequenties voor onze positie als schakel in de zorgketen}

De kosteneffectiviteit van revalidatiebehandeling bij het verbeteren van activiteiten en verhogen van participatie is onomstotelijk vastgesteld. In 2007 bedroegen in Nederland de kosten van de revalidatiezorg 395 miljoen euro maar hier stonden naar schatting 2.1 miljard Euro aan baten tegenover. 9

Echter voor zowel de patiënt als de maatschappij is nog veel meer winst te behalen door ons meer te richten op twee andere vormen van revalidatie: de prevalidatie en acute medische revalidatie.

Onder prevalidatie versta ik het adviseren en/of behandelen van patiënten zodat zij een medische behandeling kunnen ondergaan waarna eventueel weer opnieuw revalidatie kan plaatsvinden. Voorbeelden zijn de patiënt met extreme adipositas en ernstige coxarthrosis waardoor een heupvervangende operatie niet mogelijk is. Wij kunnen adviseren, coachen of zelfs een behandeling initiëren (b.v. aqua-training) waardoor de patiënt vermagert, zijn conditie opbouwt en uiteindelijk wel de heupvervangende operatie kan ondergaan. Hetzelfde geldt voor de oncologie patiënt die voorafgaand aan de oncologische behandeling fysiek/mentaal moet worden opgetraind maar bij wie deze training in de eerste lijn door complicaties niet mogelijk is. 
Een vorm van prevalidatie die we al veelvuldig toepassen is het geven van preoperatief advies over amputatieniveau en reconstructie van uitgebreide weke delen, pees- en zenuwletsels.

Bij acute medische revalidatie streven we ernaar in een zo vroeg mogelijke fase van het ziekteproces of na ongeval, zelfs als er nog medische zorg nodig is, secundaire complicaties te voorkomen en met de revalidatiebehandeling te starten. ${ }^{10}$ Uiteraard is dit niet nieuw en bestaat er b.v. in het $\mathrm{MUMC}^{+}$al vele jaren het protocol 'acute dwarslaesie', hetgeen heeft geleid tot aantoonbaar snellere en betere eindresultaten, een vermindering van het aantal complicaties en zelfs verbeterde kansen op zelfstandig functioneren en werkhervatting. ${ }^{11}$

Vandaag wil ik een tweetal nieuwe vanuit onze vakgroep geïnitieerde ketenzorg initiatieven bespreken maar ook een knelpunt, namelijk de CVA-ketenzorg in de regio Maastricht-Heuvelland.

Vroegrevalidatie op de intensive care (ERIC);

De revalidatiearts ziet de traumapatiënt op de IC, waarbij adviezen worden gegeven over positionering van patiënt in bed en eventueel operatietafel en afhankelijk van klinisch beeld en prognose schakelt hij het multidisciplinaire team in. De fysiotherapeut start met versnelde opbouw van mobilisatie, de logopedist geeft instructies ten aanzien van slikken en communicatiemiddelen, en de ergotherapeut start armhandfunctieen ADL-training en vervaardigt zonodig spalken. De maatschappelijk werkende brengt de draagkracht van het mantelzorgsysteem in kaart en ondersteunt deze zonodig en de psycholoog analyseert of er sprake is van ernstige verwerkingsproblematiek zoals posttraumatische stress stoornis of andere psychiatrische problematiek en start zo nodig begeleiding. Vroegtijdige mobilisatie bij voorkeur vierentwintig uur na het ontstaan van het letsel vermindert de kans op complicaties zoals contracturen, decubitus, pneumonie en overlijden en voorkomt blijvende beperkingen zoals ADL-afhankelijkheid en participatie problemen. ${ }^{12}$ Tevens zal de opnameduur op de IC en verpleegafdeling verkort worden. Onze vakgroep wil de meerwaarde van ERIC aantonen. Echter, uiteindelijk moet de extra personele inzet van deze zorg wel worden bekostigd en biedt de nieuwe DBC structuur hopelijk meer mogelijkheden. Mocht dit niet zo zijn dan pleit ik uitdrukkelijk voor besluitvorming die niet alleen vanuit een micro-economisch (ziekenhuis) maar vooral vanuit het macro-economisch perspectief plaatsvindt. 
Zo bedragen b.v. alleen al de door decubitus veroorzaakte maatschappelijke kosten gemiddeld 75.000 Euro per patiënt.

\section{Fast track Trauma Revalidatie Service}

In 2007 werd door het Trauma Centrum Limburg, azM en Adelante een convenant gesloten om multitraumapatiënten versneld over te plaatsen van het ziekenhuis naar het revalidatiecentrum en de revalidatiebehandeling al te starten op de traumaverpleegafdeling van het ziekenhuis. Hierbij moet $u$ vooral denken aan patiënten met complexe fracturen van zowel bovenste als onderste extremiteit, onbelastbare fracturen van de onderste extremiteiten, en bekken- en acetabulumfracturen.

Op het moment dat de patiënt medisch stabiel is, hetgeen overigens niet wil zeggen dat de medische behandeling klaar is, wordt hij binnen vijf dagen overgeplaatst naar de gespecialiseerde traumarevalidatie afdeling van Adelante. Hier vindt vervolgens onder coördinatie van chirurg en revalidatiearts de medische en revalidatiebehandeling plaats. In 2009 is deze service uitgebreid met het Atrium Medisch Centrum te Heerlen. De (kosten-) effectiviteit van deze zorgketen wordt momenteel binnen het ZonMW programma doelmatigheid wetenschappelijk geëvalueerd.

\section{CVA- ketenzorg}

Het is onomstotelijk bewezen dat het zo vroeg mogelijk mobiliseren en multidisciplinair behandelen van patiënten na het ontstaan van een beroerte leidt tot betere eindresultaten voor de patiënt en ook kosteneffectief is. ${ }^{13,14}$

Echter door budgettaire beperkingen en noodzaak om na de diagnostische fase de patiënt zo snel mogelijk vanuit het ziekenhuis in de keten door te plaatsen staat deze zorg en ook de kwaliteit daarvan onder druk. Daarbovenop staan we in Maastricht-Heuvelland voor de keuze of we de experimentele schakel in de keten, de assessment afdeling van het verpleeghuis Vivre, continueren. Vivre heeft meerdere jaren geleden een belangrijk initiatief genomen waarvan we als ketenpartners veel hebben geleerd maar waar ook uit is gebleken dat deze zorg erg en mogelijk zelfs te kostbaar is. De toekomstige inrichting van de CVAzorgketen is in de praktijk niet gemakkelijk maar het nauwgezet volgen van de CBO-richtlijn Beroerte dient hierbij leidend te zijn. ${ }^{15}$ Verder kan de besluitvorming omtrent de meest optimale vervolgbehandeling na de ziekenhuisfase worden geoptimaliseerd door inschakeling en 
intensievere betrokkenheid van de revalidatiearts.

Het is nu zaak dit vraagstuk macro-economisch te benaderen en andere spelers in het veld (provincie, gemeente, zorgverzekeraars) erbij te betrekken. Zeker als we ons realiseren dat in Limburg de vergrijzing het sterkst is van Nederland en dat er door de ontgroening een tekort aan zorgpersoneel ontstaat, kan ik me niet voorstellen dat zij aan de kant blijven staan.

Wij willen onze rol in de besluitvorming omtrent vervolgbehandeling ondersteund met een binnen het ziekenhuis eenvoudig te implementeren wetenschappelijk onderbouwd meetinstrument (Slim Meten) op ons nemen. Tevens zullen we ons inspannen en met verschillende partijen schakelen om de doorstroming van ziekenhuis naar revalidatiecentrum maar ook in een ander deel van de keten, namelijk van revalidatiecentrum naar verpleeghuis te verbeteren zodat we binnen economisch verantwoorde grenzen de kwalitatief hoogstaande zorg kunnen leveren die we al onze patiënten gunnen.

\section{Invloed van veranderingen in diagnosegroepen en demografie op de inzet van revalidatiegeneeskunde in de keten}

Ons vak is zich met name de laatste twee decennia sterk gaan richten op patiënten met chronische pijnklachten in het bewegingsapparaat die we kosteneffectieve behandelvormen kunnen aanbieden ter verbetering van voor hen relevante activiteiten en participatie.9, 16, 17

Momenteel worden de meeste poliklinische patiënten behandeld voor hersenaandoeningen en chronische pijnklachten in het bewegingsapparaat, waarbij de laatste categorie relatief meer bij vrouwen voorkomt. ' In de afgelopen vijfjaar is het aandeel van chronische pijn binnen Adelante licht gegroeid tot ongeveer 1/3, terwijl het totale aantal behandelde patiënten ook nog eens met $1 / 3$ is toegenomen. Binnen de afdeling revalidatie $\mathrm{MUMC}^{+}$is in deze periode zelfs sprake van een ruime verdubbeling die vrijwel geheel is toe te schrijven aan patiënten met chronische pijnklachten. Dit is vooral te verklaren door onze topreferente functie en beschikbaarheid van de succesvolle graded exposure behandeling. ${ }^{18-20}$

Echter het aantal mensen met een chronische ziekte en co-morbiditeit zal verder toenemen, waarbij klachten van het bewegingsapparaat op de voorgrond staan - zo rapporteert $58 \%$ van de ouderen deze klachten. ${ }^{21}$ Als we in ogenschouw nemen dat in Limburg sprake is van een 
dubbele vergrijzing en het percentage inwoners met klachten van het bewegingsapparaat reeds hoger is dan het landelijk gemiddelde en zij ook nog eens meer beperkingen en afgenomen kwaliteit van leven ervaren, ${ }^{22}$ moeten we concluderen dat er voor Limburg in vergelijking met de rest van Nederland een relatief grotere groei van de revalidatiebehandelcapaciteit noodzakelijk is. Maar gezien de huidige economische situatie valt geen grote uitbreiding van het revalidatiebudget te verwachten. Daarom zullen we moeten zoeken naar alternatieven, bijvoorbeeld samen met de geriatrische revalidatie van verpleeghuizen en het invoeren van het stepped care model met de eerste lijn en andere ketenpartners.

\section{Groeiend aanbod bij gelijkblijvende of afnemende middelen: kansen voor nieuwe en verbeterde schakels}

Stepped care

Volgens het principe van een stepped care model ontvangen patiënten een behandeling die niet uitgebreider is dan strikt noodzakelijk. Recent heeft onze vakgroep samen met de zorgverzekeraars, eerste lijn (huisartsen en fysiotherapeuten), transmurale zorg, azM-herstelzorg, Atrium en Adelante een start gemaakt met het stepped care project voor patiënten met fibromyalgie in Zuid-Limburg.

Ik wil echter eerst, zeker nu mij vandaag niemand mag tegenspreken, duidelijk stellen dat deze patiënten ook revalidatiegeneeskundige aandacht verdienen aangezien zij vaak forse beperkingen in het dagelijks leven ervaren. Verder is er duidelijk wetenschappelijk bewijs voorhanden waaruit blijkt dat er centraal neurologisch allerlei problemen spelen die de grote mate van pijngevoeligheid kunnen verklaren. ${ }^{23}$

Het stepped care project heeft als doel aan de hand van heldere criteria (o.a. ervaren beperkingen, participatieproblemen en psychosociale factoren) de minst intensieve, maximaal effectieve zorg aan te bieden terwijl periodiek de uitkomsten worden geëvalueerd. Gebruik makend van de kennis en ervaring van de revalidatiezorg, azM herstelzorg en wetenschap worden bijpassende behandelprogramma's ontwikkeld. De minder intensieve behandelvormen (b.v. advies, fysieke reconditionering, eenvoudige gedragsverandering) worden aangeboden door eerste lijn medewerkers die hiertoe specifiek geschoold en gecertificeerd zijn. Alleen patiënten met complexe onderhoudende psychosociale factoren worden binnen de revalidatiesetting behandeld merendeels 
met geprotocolleerde groepsbehandelingen. Tevens wordt een nurse practitioner opgeleid om onder verantwoordelijkheid van een revalidatiearts de indicatiestelling voor te bereiden.

Eenzelfde stepped care model werken we de komende twee jaar samen met Adelante en de andere bij het $\mathrm{MUMC}^{+}$-Spine Centre betrokken specialismen uit, om de grote toestroom van rugpijnpatiënten in een zo vroeg mogelijke fase van adequate behandeling te voorzien.

De belangrijkste schakel, de cliënt centraal

Ter illustratie een patiënt met een hoog cervicale dwarslaesie uit mijn opleidingstijd. Let wel, het is absoluut niet mijn bedoeling de integriteit en kennis van het toenmalige behandelteam ter discussie te stellen. Dit team wist aan de hand van de laesie hoogte dat ADL-zelfstandig bij deze patiënt haalbaar was en de behandeling werd pas beëindigd op het moment dat deze doelstelling was bereikt. Maar omdat de patiënt 2 uur bezig was met wassen en aankleden, schakelde hij spoedig na thuiskomst zijn mantelzorg voor het uitvoeren van de ADL in, zodat hij zijn tijd en energie kon besteden aan voor hem interessantere activiteiten. Tegenwoordig gaat een dwarslaesie patiënt nadat aan de basisvoorwaarden voor veilig thuis verblijven is voldaan, naar huis zodat hij kan ondervinden welke activiteiten hij nog wil leren en vervolgens krijgt hij de benodigde interventie aangeboden. Het mag duidelijk zijn dat deze cliëntgecentreerde aanpak leidt tot een hogere patiënt tevredenheid en efficiëntere inzet van revalidatiemiddelen. Het is echter een voorwaarde dat de patiënt een actieve rol vervult bij het formuleren van de hulpvraag. Helaas blijkt dit voor de gemiddelde patiënt niet zo eenvoudig. Vaak weet hij niet eens waarvoor hij is verwezen en al helemaal niet wat hij van ons kan verwachten. Het is dus de kunst om de patiënt onbevangen en met geduld tegemoet te treden en het gesprek aan te gaan over wat we binnen de revalidatie doen zonder meteen richting ons aanbod te sturen. De patiënt daadwerkelijk een volwaardige schakel in de keten laten zijn, is een van de belangrijkste uitdagingen voor ons vak!

Aan ons ook de taak, en ik hoop dat deze openbare lezing daar een aanzet toe geeft, om onze verwijzers beter te informeren over onze mogelijkheden en werkwijze. Hiertoe ontwikkelen we onder andere informatiemateriaal en participeren we in de huisartsen carrousel Maastricht waarbij we samen met huisartsen patiënten zien en het behandelbeleid bediscussiëren. 
Ook patiëntenbelangenorganisaties zoals bijvoorbeeld de Chronisch zieken en Gehandicaptenraad Nederland moeten meer ingeschakeld worden bij het aanpakken van de problematiek van toenemende vraag bij krimpende middelen. We moeten hierbij absoluut niet vergeten dat participatie een grondrecht is! Participatie betekent volwaardig meedoen in de samenleving. Veel mensen kunnen dat op eigen kracht, maar juist de zwakkere en kwetsbare medemensen dreigen zeker in de tegenwoordige tijd te worden uitgesloten bijvoorbeeld alleen al doordat iemand met een chronische ziekte in 2005 gemiddeld met 2.800 Euro extra kosten werd geconfronteerd. ${ }^{24}$

\section{Andere oplossingen}

Het verbeteren van onze revalidatiegeneeskundige schakels diagnostiek, indicatiestelling, behandeling en nazorg zowel in de vorm van accuraatheid en efficiency (meer betekent lang niet altijd beter!)25 is absoluut noodzakelijk en wordt ter hand genomen binnen ons wetenschappelijk onderzoek waarover ik $u$ over enkele minuten meer zal vertellen.

Uiteraard zijn er nog veel meer opties, zoals e-health toepassingen. Zo zijn we gestart met het per internet afnemen van vragenlijsten ter ondersteuning van diagnostiek en evaluatie van de pijnrevalidatiebehandeling en om per internet patiënten nazorg op het gebied van pijnrevalidatie aan te bieden. Tevens willen we een internetgebaseerde revalidatiezorg portal ontwikkelen waarin patiënten bewezen effectieve trainingsmodules bijvoorbeeld gericht op armhand vaardigheid, al dan niet onder begeleiding van behandelexperts kunnen doorlopen.

\section{Nazorg, een relatief onderbelichte schakel?}

Bij de meeste patiënten die geen progressieve aandoening of dwarslaesie hebben, wordt binnen een jaar na het stoppen van de behandeling de begeleiding door de revalidatiearts afgerond. Dit is in lijn met ons streven de patiënt zoveel mogelijk zelf verantwoordelijk te laten zijn voor het behoud van zijn functioneren. Toch vernemen we regelmatig dat patiënten behoefte hebben aan een langere follow-up. Maar alleen al vanuit beschikbare behandelcapaciteit is dit simpelweg niet haalbaar. Verder hebben we nog te weinig zicht op welke patiënten at risk zijn voor achteruitgang in functioneren. En we weten niet welke patiënten baat hebben bij extra nazorg b.v. in de vorm van advies, zelf oefenen 
met technologische ondersteuning, hernieuwde behandeling binnen revalidatie of juist eerste lijn. Ook ter verbetering van de keten in een latere fase willen we een actieve bijdrage leveren en zijn we o.a. onderzoeksprojecten op het gebied van complexe traumatologie (INTACT) en armhandvaardigheid na een beroerte (AMUSE) gestart.

\section{Grenzen van het vak}

De kennis die we hebben opgedaan bij het behandelen van chronische aandoeningen van o.a. het bewegingsapparaat lijkt prima toepasbaar bij het aanpakken van beperkingen die samenhangen met een veranderde leefstijl zoals diabetes en obesitas. Ik ben van mening dat we deze doelgroepen niet binnen de revalidatie, d.w.z. onder eindverantwoordelijkheid van de revalidatiearts moeten behandelen maar wel onze expertise/kennis voor andere partijen ter beschikking moeten stellen.

Als uit de multicentre gerandomiseerde studie FATIGO, die vanuit het revalidatiecentrum Breda onder begeleiding van onze vakgroep wordt uitgevoerd, blijkt dat de revalidatiebehandeling voor mensen met het chronisch vermoeidheidssyndroom kosteneffectief is in vergelijking met enkelvoudige psychologische begeleiding, dan dient deze interventie in ons reguliere behandelaanbod te worden opgenomen (www.fatigo-cvs. nl). Het feit dat deze mensen ook zeer vaak pijn in het bewegingsapparaat rapporteren is hierin wat mij betreft doorslaggevend.

\section{Noodzaak tot academiseren}

Vanuit de maatschappij (ziektekostenverzekeraars, burgers, overheid) en de beroepsgroep bestaat er toenemend behoefte aan wetenschappelijke onderbouwing van de door ons geleverde zorg. Enerzijds is dit nodig voor de verantwoording van de financiering van zorg, anderzijds voor het 'evidence based' werken en uiteindelijk de kwaliteitsverbetering van de revalidatiezorg.

Samen met Adelante heeft de afdeling revalidatie en vakgroep $\mathrm{MUMC}^{+}$een sterke schakel c.q. tandem gevormd om de positie van de revalidatiegeneeskunde in de zorgketen te verstevigen en de academisering vorm te geven. Aangezien we de ambitie hebben om uit te groeien tot een internationaal expertisecentrum op het gebied van de revalidatiegeneeskunde leveren we naast de reguliere zorg ook topklinische/topreferente zorg en hebben we het wetenschappelijk 
onderzoek en een deel van het onderwijs, met deze speerpunten gelijk geschakeld.

De afdeling revalidatie $\mathrm{MUMC}^{+}$wil zich naast het aanbieden van reguliere zorg, spasticiteitbestrijding bij kinderen met een cerebrale parese (CP) en de intrathecale baclofenpomp voor volwassenen, vooral profileren op het gebied van chronische pijnklachten in het bewegingsapparaat voor zowel adolescenten als volwassenen. Voor de klinische zorg ligt de focus op de vroegrevalidatie van multitraumapatiënten.

Bij de toenemende belasting door het meer aanbieden van onderwijs, reeds lopend en nog gepland wetenschappelijk onderzoek en de forse groei in het aantal poliklinische behandelde patiënten, blijkt de bestaande organisatiestructuur van de afdeling revalidatie $\mathrm{MUMC}^{+}$ niet meer passend om de kwalitatief hoogstaande academische zorg in de toekomst te kunnen garanderen. Daarom wordt op korte termijn in samenwerking met Adelante een voorstel tot het implementeren van een nieuwe organisatiestructuur van de afdeling voorgelegd.

Binnen Adelante zijn naast chronische pijn, ook revalidatie van complexe arm-handvaardigheidsproblematiek bij volwassenen en kinderen en complexe traumarevalidatie als topklinische speerpunten van zorg benoemd.

Doordat de afdeling revalidatie $\mathrm{MUMC}^{+}$samen met Adelante de beschikking heeft over het totale pakket van pijnrevalidatiebehandeling, inclusief nieuwe zorgproducten, kunnen we binnen het $\mathrm{MUMC}^{+}$ uitstekend aansluiten bij de wensen van het Spine Centre, de polikliniek pijnbestrijding en het multidisciplinair pijnteam. Tevens dragen we gezamenlijk zorg voor een adequate invoering van de eerder genoemde stepped care voor fibromyalgie patiënten (niet alleen zorg maar ook scholing) met als partners azM herstelzorg en de eerste lijn.

\section{Wetenschappelijk onderzoek}

Het wetenschappelijk onderzoek wordt verricht vanuit de vakgroep en het kenniscentrum Adelante en is als zelfstandig onderzoekprogramma ondergebracht bij de onderzoeksschool Caphri van de Universiteit Maastricht. Caphri is het 'Care and public health research institute' en richt zich op multidisciplinair onderzoek met een primaire focus op gezondheid gerelateerde uitkomsten. 
Het onderzoek sluit naadloos aan bij de zojuist genoemde topklinische speerpunten van zorg binnen Adelante en het $\mathrm{MUMC}^{+}$. Het betreft toegepast (patiëntgebonden) en ten dele translationeel onderzoek en is primair gericht op het onderbouwen, verbeteren en implementeren van (kosten-) effectieve revalidatiegeneeskundige indicatiestelling, behandeling en nazorg.

Door de tijdslimiet beperk ik me nu tot de hoofdlijnen en voor het volledig overzicht verwijs ik naar het onderzoeksplan revalidatiegeneeskunde voor de periode 2011-2015.

\section{Chronische pijn}

We willen onze kennis over verklaringsmechanismen voor de ervaren beperkingen in functioneren en participatie ten gevolge van pijnklachten vergroten en op basis hiervan nieuwe strategieën voor diagnostiek en behandeling ontwikkelen, toepassen en toetsen.

Binnen deze onderzoekslijn hebben we mede door een uitstekende nationale en internationale samenwerking naar een hogere versnelling kunnen schakelen hetgeen blijkt uit de grote hoeveelheid lopende onderzoeksprojecten:

- We onderzoeken de (kosten)effectiviteit van verschillende behandelstrategieën zoals motivational interviewing voor start van pijnrevalidatie, Transcutaneous Electrical Nerve Stimulation (TENS), graded exposure bij het complex regionaal pijnsyndroom type I (CRPS-I), internet ondersteunde spiegeltherapie bij fantoompijn, mood-as input bij klachten arm, nek en schouder (KANS), preventie van pijnklachten bij musici en multidisciplinaire revalidatie bij het chronisch vermoeidheidssyndroom. Daarnaast proberen we bij al deze studies meer te weten te komen over de onderliggend werkingsmechanismen en meer inzicht te krijgen in welke kenmerken van patiënten positief of juist negatief voorspellend zijn voor het succes van de aangeboden interventie.

- Bij jongeren met pijn in het bewegingsapparaat wordt een observationele studie naar de (kosten)effectiviteit van in Nederland aangeboden revalidatiebehandeling en de daarbij behorende werkingsmechanismen uitgevoerd. En er worden meerdere procesen uitkomstmaten ontwikkeld en gevalideerd.

- Een voor de pijnrevalidatie zeer interessant en relatief nieuw topic 
is hoe we verschillende beweegstrategieën kunnen onderscheiden. Hierbij moet $u$ denken aan mensen die ondanks pijn maar steeds blijven doorgaan of vanwege de pijn juist vele activiteiten vermijden. We willen achterhalen welke drijfveren vanuit de persoon (zoals b.v. identiteit) hiermee samenhangen.

- Het meest recente onderzoek richt zich op het vinden van verklaringsmechanismen voor ervaren beperkingen en participatieproblemen van patiënten met neuropathische pijn bij diabetes mellitus.

- Maar we doen ook onderzoek samen met een andere belangrijke schakel namelijk de collega's in de dagelijkse praktijk; onder onze regie wordt door de vier Ontwikkelcentra PijnRevalidatie bij 45 revalidatie-instellingen een set van prognostische en evaluatieve meetinstrumenten voor pijnrevalidatie geïmplementeerd. Deze landelijke dataset wordt gebruikt voor benchmarking (normdata) en kwaliteitscontrole, maar bovenal verschaft het waardevolle informatie over de effectiviteit, werkingsmechanismen en het bestaan van mogelijke subgroepen.

In totaal lopen er 8 promotietrajecten. Met name Johan Vlaeyen en Madelon Peters ben ik zeer erkentelijk voor de uiterst prettige en vruchtbare samenwerking.

Binnen deze onderzoekslijn voeren Jeanine Verbunt, coördinator van deze lijn, Marielle Goossens, Jeroen de Jong, Joop Ruijgrok, Marjon van Eijsden, Ivan Huijnen, Hanne Kindermans, Albere Köke en ondergetekende samen met de promovendi een grote hoeveelheid lopende projecten uit en worden meerdere projectaanvragen voorbereid.

\section{Armhandvaardigheid volwassenen en kinderen}

Het accent ligt bij de lijn volwassenen op:

- De effectiviteit van bestaande en nieuwe interventies die gebruik maken van ontwikkelingen uit technologie, trainingsfysiologie, motorische leertheorieën en functieleer/psychologie. Enkele voorbeelden voor de patiënten met een beroerte zijn mental practice, patiëntgerichte technologie ondersteunde taakgerichte training, revalidatierobotica, sensortechnologie gegeneerde feedback en virtual reality en modulaire armhandvaardigheid training bij cervicale dwarslaesie patiënten. Enkele van deze interventies worden specifiek in de nazorg fase onderzocht. 
- Aangezien dit een vrij onontgonnen onderzoeksgebied betreft worden meetinstrumenten ter kwantificering van de kwaliteit van de armhandvaardigheid ontwikkeld. Tevens vindt er translationeel onderzoek plaats zoals het beoordelen van de toegevoegde waarde van persuasieve technologie in samenwerking met o.a. TU Eindhoven en onderzoek naar de onderliggende mechanismen o.a. in samenwerking met de vakgroep bewegingswetenschappen Universiteit Maastricht.

Vorig jaar zijn twee promotietrajecten afgerond en is er een gestart.

Binnen deze onderzoekslijn werken Henk Seelen, coördinator van deze lijn, Annick Timmermans, Annemie Spooren, Sascha Rasquin, Ananda Hochstenbach, Han Frank en Richard Geers aan vele projecten en projectaanvragen in samenwerking met vele partners in binnen- en buitenland.

De onderzoekslijn armhandvaardigheid kinderen betreft vooral het bepalen van de effectiviteit van interventies bij kinderen met CP

- Intensieve functionele taakgerichte krachttraining van de bovenste extremiteit, constrained induced movement therapy-kamp en intensieve bimanuele vaardigheidstraining al dan niet voorafgegaan door botuline toxine behandeling (BoBiVa).

- Ook dit onderzoeksgebied is relatief jong en daarom worden meetinstrumenten voor o.a. functionele kracht en armhandvaardigheid bij CP en obstetrisch plexus brachialis letsel (OPBL) ontwikkeld en geëvalueerd.

- Verder wordt de toepasbaarheid van interactieve computer games en technologie ondersteuning voor training geïnventariseerd.

Er loopt momenteel een promotietraject.

Binnen deze onderzoekslijn werken Yvonne Janssen-Potten, coördinator van deze lijn, Eugene Rameckers, Nienke Haga, Lucianne Speth en Marcel Koenen. Er bestaat een goede samenwerking met de afdeling kinderneurologie en vele andere nationale en internationale partners. 


\section{Complexe traumatologie}

Het accent van deze onderzoekslijn ligt op het bepalen van de kosteneffectiviteit van het anders inrichten van de zorgketen.

- De projecten vroegrevalidatie op IC, fast track revalidatie service en de identificatie van complexe traumapatiënten at risk voor verminderd functioneren na revalidatiefase heb ik reeds besproken. Uiteindelijk zal dit laatste project resulteren in het ontwikkelen en evalueren van een nieuw nazorgtraject.

- Verder wordt binnenkort de ontwikkeling en evaluatie van een meetinstrument op activiteiten en participatieniveau voor amputatiepatiënten (Assessment of Daily Activity Performance in Transfemoral amputees; ADAPT) afgerond en is recent gestart met de evaluatie van postoperatieve stomp oedeembestrijding met een afneembare rigid dressing gevolgd door siliconen liners.

Dit jaar wordt een promotieonderzoek afgerond. Ik wil speciaal Peter Brink bedanken voor de uitstekende samenwerking.

Binnen deze lijn werken Bea Hemmen, coördinator van deze lijn, Patrick Theeven, Ans Bouman en Henk Seelen. Er wordt zeer intensief samengewerkt met de afdeling traumatologie azM.

\section{Methodologische uitdagingen}

Zoals we onlangs beschreven, gaat het doen van onderzoek binnen de revalidatiegeneeskunde gepaard met allerlei specifieke methodologische problemen. ${ }^{26}$ Voor het aantonen dat een interventie effectief is geldt de randomized controlled trial (RCT) als het ultieme bewijs. Er bestaan echter voorbeelden waarbij ondanks het ontbreken van een RCT de interventie niet in twijfel wordt getrokken en toch wordt toegepast zoals insuline voor diabetes of het gebruik van een parachute bij een sprong uit een vliegtuig!

Maar het kan voorkomen dat een interventie wordt ontwikkeld die zo effectief is dat je vanwege allerlei praktische zaken nauwelijks nog een adequate RCT kunt uitvoeren. We zien nu hoe lastig het is om bij graded exposure voor patiënten met CRPS-I, waarbij de indicerend arts niet altijd afdoende geblindeerd kan blijven voor het verschil in resultaten tussen de interventies, geleidelijk aan ethische bezwaren ontwikkelt tegen het insluiten van patiënten voor deze studie en daarmee de haalbaarheid van de studie in gevaar komt. Dit, maar ook de forse tijd- en kosteninvestering die aan een RCT verbonden zijn 
vraagt om andere designs zoals de $\mathrm{N}=1$ studie. Met dit design is het effect van graded exposure overduidelijk aangetoond maar helaas worden bij meta-analyses deze studies ondanks een hoge mate van statistische bewijskracht (nog steeds) als methodologisch zwak gezien. Dit had onlangs tot gevolg dat een subsidieaanvraag om de graded exposure behandeling in revalidatieteams te implementeren niet werd gehonoreerd. Gelukkig hebben we de zorgverzekeraars wel bereid gevonden om deze interventie, via een intensieve training en supervisie te implementeren in enkele Limburgse revalidatieteams.

Nu er sprake is van een krimpende subsidiemarkt zeker op het gebied van onafhankelijke fondsen, zal de onderlinge competitie toenemen. $\mathrm{Nu}$ is competitie niet verkeerd, maar ik pleit er nadrukkelijk voor dat het toekennen van subsidies niet vertroebeld wordt door politieke belangen zoals geografische spreiding van gelden. Vaak gaat de besluitvorming uitstekend, zeker als met externe niet belanghebbende referenten worden gewerkt, soms echter niet.

verder moeten we als vakgroepen revalidatiegeneeskunde over onze eigen schaduw heen durven stappen en nog intensiever samenwerken.

\section{Implementatie en innovatie, verbindende schakels}

Wetenschappelijk onderzoek is alleen zinvol als de opgedane kennis en bewezen effectieve zorg in de dagelijkse praktijk worden geïmplementeerd en omgekeerd onderzoekers door de 'werkvloer' worden gevoed met vragen en innovatieve ideeën. Binnen Adelante en revalidatieteams $\mathrm{MUMC}^{+}$en Atrium, zijn twee medewerkers innovatie aangesteld die een coördinerende en faciliterende rol naar professionals in het primaire proces vervullen bij het ontwikkelen, uitvoeren en evalueren van innovaties in de zorg. Hierbij ligt de nadruk op de vier topklinische functies en nieuwe zorgproducten die op basis van de zojuist afgeronde portfolio analyse binnen Adelante zijn geïdentificeerd. Verder begeleiden zij behandelteams bij het evidence based vormgeven van zorgprogramma's. Vervolgens vindt periodieke evaluatie van het programma aan de hand van proces en uitkomstmetingen plaats, gevolgd door eventuele bijstelling van het zorgprogramma waarmee de Plan, Do, Check, Act-cyclus volledig wordt doorlopen.

\section{Onderwijs, de toekomstige schakel}

Voor ons is het belangrijk om de onderwijsbijdrage aan studenten geneeskunde te vergroten. Allereerst willen we dat alle toekomstige dokters meer aandacht hebben voor de functionele en sociale gevolgen 
van ziekte en weten wat de revalidatiegeneeskunde te bieden heeft. Ook willen we een deel van hen vroegtijdig interesseren en werven voor de medische vervolgopleiding revalidatiegeneeskunde. Hiertoe zijn we actief betrokken bij het blok bewegingsapparaat in jaar 3, onderwijspoli's en de stage sociale geneeskunde en bieden we keuze co-schappen, stageplekken gezondheidszorg (GEZP), en onderzoek (WESP/AKO) aan.

De afgelopen twee jaar hebben meerdere collega revalidatieartsen van Adelante en het $\mathrm{MUMC}^{+}$extra tutorrollen binnen het bachelor onderwijs vervuld en enkele nieuwe colleges verzorgd.

Echter door bezuinigingen binnen het onderwijsinstituut zijn de financiële vergoedingen ontoereikend en wordt er naarstig naar een oplossing gezocht om te voorkomen dat we voor de gewetensvraag worden gesteld of we de inzet van onze collega revalidatieartsen als tutoren kunnen continueren.

$\mathrm{Na}$ jaren van alleen aanbieden van wetenschapsstages aan studenten bewegingswetenschappen, hebben we dit academisch jaar fors geïnvesteerd in deelname van planningsgroepen binnen het nieuwe curriculum bachelor bewegingswetenschappen. Hiermee willen we gemotiveerde en getalenteerde studenten interesseren voor master afstudeerprojecten en eventuele promotietrajecten binnen ons onderzoeksprogramma.

Tot slot, willen wij vanuit de onderzoekslijn chronische pijn, meer betrokken zijn bij de studie geestelijke gezondheidskunde, voornamelijk door het aanbieden van afstudeerprojecten.

Hiermee ben ik bijna aan het einde van mijn rede gekomen en hoop ik $u$ allen een goed inzicht in mijn visie en reisplannen te hebben geven. Ik ben ervan overtuigd dat onze vakgroep samen met Adelante over een spreekwoordelijke betrouwbare fiets met voldoende schakelvermogen beschikt om de professionele eindbestemming namelijk een volwaardige academisering, te bereiken. In het verleden heb ik met mijn eigen stalen ros mijn persoonlijke eindbestemming al mogen bereiken, maar voor deze ontdekkingsreis was en is de hulp van vele andere mensen onontbeerlijk. Daarom eindig ik met een woord van dank.

Ik dank de rector, het college van bestuur, oud-decanen Harry Hillen en Martin Paul voor het in mij gestelde vertrouwen. Ik dank Gauke Kootstra, die mij als interim directeur van Adelante in 2007 benaderde met het 
wilde plan om mij voor te dragen voor deze leerstoel. Mijn vrouw José en ik voelen ons nog altijd uitermate bevoorrecht en verrijkt met de mogelijkheid die jij ons namens Adelante bood om een jaar als research fellow in Sydney te gaan werken. Adelante verdient nog een bijzondere vermelding. Zonder de inzet en financiële steun vanuit deze organisatie met een duidelijke visie en mooie ambities zou de academisering nog steeds niet van de grond zijn gekomen. Anke Meijs en Jean Paul Essers, de raad van bestuur tijdens de eerste periode van mijn hoogleraarschap, bedankt voor jullie steun in de voor ons allemaal zeker niet gemakkelijke opstartfase. Pieter van Dreumel, de nieuwe voorzitter van de raad van bestuur Adelante, samen met jou en vele anderen wil ik de ingezette academisering verder uitbouwen.

Onno van Schayck, directeur van Caphri en alle andere Caphri medewerkers bedankt voor het instellen van het zelfstandig programma revalidatiegeneeskunde. Speciaal woord van dank aan de mensen die aan de wieg hebben gestaan van mijn wetenschappelijke carrière; mijn promotores Johan Vlaeyen en André Knottnerus, mijn politieke raadgever en klankbord. Mijn vorige werkgever Blixembosch die mij in de gelegenheid stelde om promotieonderzoek te doen. De uitnodiging tot intensievere samenwerking op het gebied van onderzoek en opleiding staat nog steeds. Speciaal wil ik mijn beste collega en vriend Hans Maarten Kruitbosch bedanken. Dankzij jouw relativeringvermogen en positivisme heb ik me zeker verder kunnen ontwikkelen. Ik ben blij dat je er vandaag bij bent!

Ook een speciaal woord van dank aan Prof Derick Wade die de jarenlang zijn expertise voor onze vakgroep in de dop beschikbaar heeft gesteld en de vakgroep Huisartsgeneeskunde die onze vakgroep toen die nog niet officieel bestond onderdak en geweldige ondersteuning heeft geboden!

Mijn plannen zijn allemaal niet mogelijk zonder de steun van mijn vakgroepleden, onderzoekscoördinatoren Henk, Yvonne, Bea en Jeanine, alle promovendi en ondersteunende medewerkers zowel op de universiteit als het Adelante Kenniscentrum. Ik wil hierbij speciaal Jeanine Verbunt en Henk Seelen noemen. Dankzij jullie lag er al een zeer stevige basis voor ons ambitieuze onderzoeksplan. Margareth van Krevel bedankt voor de zoals gewoonlijk perfecte organisatie van vandaag en het claimen van de werkkamers op de UM. De stafleden, behandelaars, manager bedrijfsvoering en administratieve medewerkers van de afdeling revalidatie $\mathrm{MUMC}^{+}$die momenteel bruist van de ambities. 
De directie van de RVE Klinische Neurowetenschappen en directie het $\mathrm{MUMC}^{+}$met een speciaal woord van dank aan Koo van Overbeeke die me op een zeer cruciaal moment uitstekend heeft gesteund!

Al onze nationale en internationale samenwerkingspartners zowel in zorg, onderzoek en de opleiding tot revalidatiearts. Ik wil hier vooral de Hogeschool Zuyd en Revant te Breda noemen.

Ik dank al onze vrienden en familieleden voor de mooie en gezellige tijden van afleiding en vermaak maar ook boeiende discussies. Ik dank vooral mijn broer Wil, schoonzus Patricia en mijn vader en moeder voor hun warme belangstelling en steun. Ik weet dat jullie enorm trots op mij zijn maar ik ben dat ook op jullie!

Nu niet zoals bij de promotie als eerste maar als laatste. José woorden schieten tekort voor de onaflatende steun en liefde die je mij hebt geschonken. Ik voel me een enorme geluksvogel met jou aan mijn zijde!

Ik heb gezegd! 
1. Revalidatie Nederland. Revalidatie Brancherapport 2009. 2010, Utrecht: Revalidatie Nederland.

2. Evenblij M. Voorspellen van herstellen. Uitkomsten van revalidatieonderzoek. 2008, België: Die Keure.

3. Gutenbrunner C, Ward AB, Chamberlain MA. White book on Physical and Rehabilitation Medicine in Europe. J Rehabil Med, 2007(45 Suppl): p. 6-47.

4. Stucki G, Melvin J. The International Classification of Functioning, Disability and Health: a unifying model for the conceptual description of physical and rehabilitation medicine. J Rehabil Med, 2007. 39(4): p. 286-92.

5. WHO. The International Classification of Functioning, Disability and Health (ICF). 2nd ed. 2001, Geneva, Switzerland: WHO.

6. Buchbinder R, Jolley D. Population based intervention to change back pain beliefs: three year follow up population survey. BMJ, 2004. 328(7435): p. 321.

7. Buchbinder R, Jolley D, Wyatt M. 2001 Volvo Award Winner in Clinical Studies: Effects of a media campaign on back pain beliefs and its potential influence on management of low back pain in general practice. Spine, 2001. 26(23): p. 2535-42.

8. Gross DP et al. Evaluation of a Canadian back pain mass media campaign. Spine, 2010. 35(8): p. 906-13.

9. Kok L, Houkes A, Niessen N, eds. Kosten en baten van revalidatie. SEO-rapport nr. 200868, 2008, SEO Economisch Onderzoek Amsterdam: Amsterdam.

10. Ward $A B$ et al. European Union of Medical Specialists (UEMS) section of Physical \& Rehabilitation Medicine: a position paper on physical and rehabilitation medicine in acute settings. J Rehabil Med, 2010. 42(5): p. 417-24.

11. Worthington AD, Oldham JB. Delayed discharge from rehabilitation after brain injury. Clin Rehabil, 2006. 20(1): p. 79-82.

12. Glaesener JJ. Acute rehabilitation after trauma-concepts and outcomes. J Rehabil Med 2008. 40(47): p. 195.

13. Indredavik B et al. Benefit of a stroke unit: a randomized controlled trial. Stroke, 1991. $22(8)$ : p. 1026-31.

14. Langhorne P et al. Early supported discharge services for stroke patients: a meta-analysis of individual patients' data. Lancet, 2005. 365(9458): p. 501-6.

15. Nederlandse Vereniging voor Neurologie. CBO richtlijn diagnostiek, behandeling en zorg voor patiënten met een beroerte. 2008, Utrecht.

16. Karjalainen KA et al. Multidisciplinary rehabilitation for fibromyalgia and musculoskeletal pain in working age adults. Cochrane Database of Systematic Reviews: Reviews 1999 Issue 3 John Wiley \& Sons, Ltd Chichester, UK DOI: 10.1002/14651858.CDoo1984, 1999(3).

17. Turk DC, Okifuji A. Treatment of chronic pain patients: clinical outcomes, costeffectiveness, and cost-benefits of multidisciplinary pain centers. Critical Reviews in Physical Rehabilitation Medicine, 1998. 10: p. 181-208. 
18. de Jong JR et al. Fear of movement/(re)injury in chronic low back pain: education or exposure in vivo as mediator to fear reduction? Clin J Pain, 2005. 21(1): p. 9-17; discussion 69-72.

19. den Hollander $M$ et al. Fear reduction in patients with chronic pain: a learning theory perspective. Expert Reviews Neurotherapeutics, 2010. 10: p. 1733-45.

20. Leeuw $M$ et al. Exposure in vivo versus operant graded activity in chronic low back pain patients: results of a randomized controlled trial. Pain, 2008. 138(1): p. 192-207.

21. Gezondheidsbevordering GGD Zuid Limburg. Seniorenmonitor 2008, Rapportage regio Zuid-Limburg. Eerste resultaten van een onderzoek naar gezondheid, leefstijl, welzijn en zorg van zelfstandig wonende 55-plussers. 2009, Geleen.

22. RIVM. Nationale Atlas Volksgezondheid, versie 4.3, http://www.zorgatlas.nl/gezondheiden-ziekte/functioneren-en-kwaliteit-van-leven/personen-met-beper-kingen-inbewegen-2005-2008/ and http://www.zorgatlas.nl/gezondheid-en-ziekte/functionerenen-kwaliteit-van-leven/minder-goede-ervaren-gezondheid-per-ggd-regio-2005-2008. 2011.

23. Clauw DJ. Fibromyalgia: an overview. Am J Med, 2009. 122 (12 Suppl): p. S3-S13.

24. Bos J et al. Meerkosten in Kaart. Een onderzoek naar de financiële positie van chronisch zieken en gehandicapten. 2007, Utrecht: Chronisch zieken en Gehandicapten Raad.

25. Smeets R.J et al. More is not always better: cost-effectiveness analysis of combined, single behavioral and single physical rehabilitation programs for chronic low back pain. Eur J Pain, 2009. 13(1): p. 71-81.

26. Wade DT, Smeets RJ, Verbunt JA. Research in rehabilitation medicine: methodological challenges. J Clin Epidemiol, 2010. 63(7): p. 699-704. 
